\title{
Early Action to Address an Emerging Wildlife Disease
}

A deadly fungal pathogen, Batrachochytrium

salamandrivorans ( $\mathrm{Bsal}$ ) that affects amphibian skin was discovered during a die-off of European fire salamanders (Salamandra salamandra) in 2014. This pathogen has the potential to worsen already severe worldwide amphibian declines. Bsal is a close relative to another fungal disease known as Batrachochytrium dendrobatidis $(B d)$. Many scientists consider $B d$ to be the greatest threat to amphibian biodiversity of any disease because it affects a large number of species and has the unusual ability to drive species and populations to extinction.

Although not yet detected in the United States, the emergence of Bsal could threaten the salamander population, which is the most diverse in the world. The spread of Bsal likely will lead to more State and federally listed threatened or endangered amphibian species, and associated economic effects (fig. 1).

Because of the concern expressed by resource management agencies, the U.S. Geological Survey (USGS) has made Bsal and similar pathogens a priority for research.

\section{Preparing for Invasion}

An emerging infectious disease is a new disease that rapidly increases in incidence or quickly spreads in geographic range. Typically, the response to emerging infectious diseases has been reactionary; actions to contain the outbreaks happen after the disease has reached crisis levels. One recent example is with white-nose syndrome in bats, which arrived and rapidly spread in the United States causing catastrophic mortality while management agencies began their response.

Our knowledge of the threat of Bsal prior to its detection in the United States is unprecedented and offers a unique chance to develop and implement a coordinated response before observing any significant negative biological and economic effects.

The USGS provides unbiased science and research to support the U.S. Fish and Wildlife Service (USFWS) and other U.S. Department of the Interior bureaus in their response to this threat on the amphibian population of the United States. A proactive approach to the threat of Bsal includes the following actions:

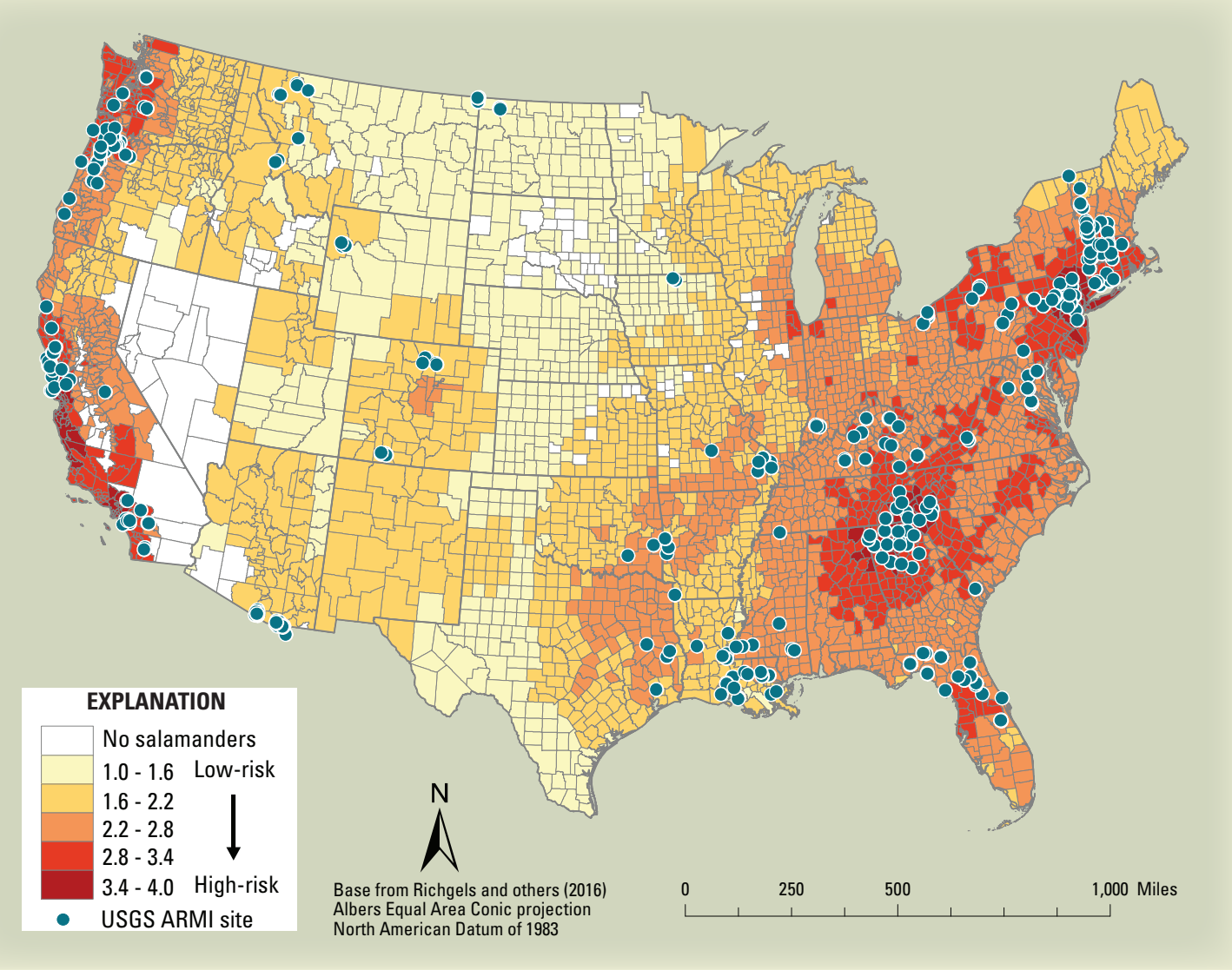

Figure 1. Relative risk for Bsalintroduction by county in the United States. Sites indicate where the U.S. Geological Survey Amphibian Research and Monitoring Initiative (ARMI) has sampled wild populations of amphibians in an effort to detect and contain Bsal. 


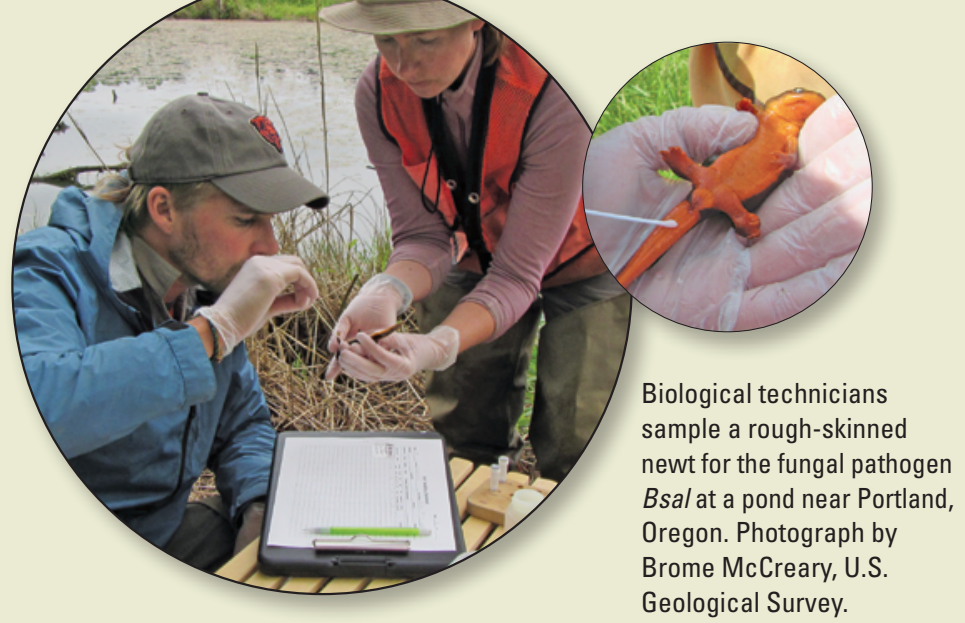

- The USGS led a workshop in June 2015 to identify Bsal management actions and research needs. Workshop participants included international scientific research institutions, zoological parks, resource management agencies, and states. Grant and others (2016) details key findings from this workshop.

- The USGS led the formation of the Bsal Task Force (http://www.salamanderfungus.org/), to ensure a coordinated approach to the Bsal threat in the United States. The Task Force includes representatives from the National Park Service, USFWS, U.S. Forest Service, states, universities, zoos, nongovernmental organizations, and the government of Canada.

- The USGS National Wildlife Health Center completed a risk analysis showing areas in the United States that are at highest risk for the emergence of Bsal (fig. 1).

- USGS science was used by the USFWS to support their Lacey Act interim ruling listing 201 salamanders as "injurious" (https://www.regulations.gov/document?D=FWS-HQFAC-2015-0005-0001, accessed January 12, 2016).

- The USGS Amphibian Research and Monitoring Initiative (ARMI; https://armi.usgs.gov/) is presently monitoring highrisk areas for Bsal to support early response to this threat (fig. 1).

\section{Amphibians...Why Care?}

Amphibians are the most endangered animals in the world. The United Nations International Union for the Conservation of Nature reports an estimated 42.5 percent of the world's amphibians are threatened at some level (Stuart and others, 2004).

Amphibians live in forest and aquatic habitats throughout the United States. These habitats provide fishing, hunting, wildlife watching, and recreational opportunities that support local businesses and contribute billions of dollars to the overall economy of the United States.

Although not as obvious as birds and mammals, amphibians can easily be the most abundant animals in their ecosystems and play multiple important roles. Amphibians eat large numbers of insects, which indirectly affects processes such as the transmission of human disease and the decomposition of leaves and wood on forest floors. Their effect on decomposition is so great that it ultimately affects the global carbon cycle. Amphibians also are an important food source for a large variety of other wildlife.

ARMI provides scientific information to help managers conserve this vital component of biodiversity.

\section{Key Facts}

- Bsal is a fungal pathogen that began causing high mortality in European salamander populations in 2014.

- Bsal can potentially be spread by the international pet trade.

- More than 28 million amphibians were imported to the United States during a 6-year period (2000-2005).

- The highest salamander diversity in the world is in the United States and some of these species are known to be susceptible to Bsal.

- Amphibians are the most threatened group of animals in the world.

\section{Selected References}

Adams, M.J., Miller, D.A., Muths, Erin, Corn, P.S., Campbell Grant, E.H., Bailey, L.L., Fellers, G.M., Fisher, R.N., Sadinski, W.J., Waddle, Hardin, and Walls, S.C., 2013, Trends in amphibian occupancy in the United States: PLOS One, http://dx.doi. org/10.1371/journal.pone.0064347.

Best, M.L., and Welsh, H.H. Jr., 2014, The trophic role of a forest salamander: Impacts on invertebrates, leaf litter retention, and the humification process: Ecosphere, v. 5, no. 2, p. 1-19, http://dx.doi. org/10.1890/ES13-00302.1.

Fisher, M.C., Henk, D.A., Briggs, C.J., Brownstein, J.S., Madoff, L.C., McCraw, S.L., and Gurr, S.J., 2012, Emerging fungal threats to animal, plant and ecosystem health: Nature, v., 484, p. 186-194, http://dx.doi.org/10.1038/nature10947.

Grant, E.H.C., Muths, E., Katz, R.A., Canessa, Stefano, Adam, M.J., Ballard, J.R., and others, 2016, Salamander chytrid fungus (Batrachochytrium salamandrivorans) in the United StatesDeveloping research, monitoring, and management strategies: U.S. Geological Survey Open-File Report 2015-1233, 16 p., http:// dx.doi.org/10.3133/ofr20151233.

Richgels, K.L.D., Russell, R.E., Adams, M.J., White, C.L., and Campbell Grant E.H., 2016, Spatial variation in risk and consequence of Batrachochytrium salamandrivorans introduction in the USA: Royal Society Open Science 3, http://dx.doi. org/10.1098/rsos.150616.

Semlitsch, R.D., O’Donnell, K.M., and Thompson, F.R., 2014, Abundance, biomass production, nutrient content, and the possible role of terrestrial salamanders in Missouri Ozark forest ecosystems: Canadian Journal of Zoology, v. 92, no. 12, p. 997-1,004.

Skerratt, L.F., Berger, Lee, Speare, Rick, and Kenyon, Nicole, 2007, Spread of chytridiomycosis has caused the rapid global decline and extinction of frogs: EcoHealth, v. 4, no. 2, p. 125-134.

Stuart, S.N., Chanson, J.S., Cox, N.A., Young, B.E., Rodrigues, A.S.L., Fischman, D.L., and Waller, R.W., 2004, Status and trends of amphibian declines and extinctions worldwide: Science, v. 306, p. 1,783-1,786.

Authors: Michael J. Adams, M. Camille Harris, and Daniel A. Grear.

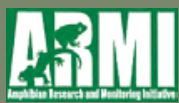

For more information:

Director, Forest and Rangeland Ecosystem Science Center

U.S. Geological Survey,

777 NW 9th St., Suite 400, Corvallis, Oregon 97330 http://usgs.gov/fresc

Publishing support provided by the U.S. Geological Survey, Science Publishing Network, Tacoma Publishing Service Center 